\title{
Gender Paradox and Women's Spatiality: A Case Study of "Mothers Accompanying Children in Education" at the Chiang Mai Chinese Christian Church
}

\author{
Xiaoxia Lan* and Aranya Siriphon \\ Faculty of Social Sciences, Chiang Mai University, Chiang Mai 50200, Thailand \\ ${ }^{*}$ Corresponding author. E-mail :gragonlan88@hotmail.com \\ https://doi.org/10.12982/CMUJASR.2020.002
}

\begin{abstract}
This article explores a group of new Chinese migrant "peidu mamas" or "mothers accompanying children in education" in the Chiang Mai city, Thailand. By using ethnography as the research methodology, this article examines the gender role and women's spatiality issues that exist between the church and the community. After interviewing informants and doing participation observation at Chiang Mai Huaren Jidu Church for several months, the researchers unravel how the "peidu mamas" in the church have faced an extreme level of gender paradox and gender hierarchy while participating in the church activities. These "peidu mamas" strategically utilize Christian interpretation by deploying the traditional Chinese concept with regards to "obedience" and "reserved patriarchal bargaining." It is an attempt to reduce the inferior status encountered by the female Chinese Christian "peidu mamas" and to negotiate the paradoxical Confucianism beliefs regarding gender hierarchy and family values.
\end{abstract}

Keywords: Gender paradox, Patriarchal bargain, Spatiality

\section{INTRODUCTION}

The rising number of new Chinese immigrants in Southeast Asia in the past three decades has caused an increased number of Chinese Christian churches in Chiang Mai city. These newly established Chinese diaspora Christian churches in recent years focus on the new Chinese diaspora through employing overseas Chinese pastors and using solely Mandarin as a means to communicate. Set up in September 2015, Chiang Mai Huaren Jidu Church has become one of the fastest growing Chinese diaspora churches with about 60 regular members and 40 nonregular members.

Chiang Mai Huaren Jidu Church is a typical Chinese diaspora church that has played a major role in building a sense of belonging and maintaining the identity of the new Chinese diaspora. The church conducts its operations in a practical manner through using the Mandarin language, preparing Chinese food, and organizing Chinese cultural activities. These activities, including the celebration of Chinese 
traditional holidays and other family-oriented activities, have helped the church members in educating their children.

More than 60 percent of church members in Chiang Mai Huaren Jidu Church are "peidu mamas." Literally, "peidu" means "accompany in study," and "mama" means "mother." In other words, they are mothers accompanying their children who are receiving education in a foreign place. Over the recent years, Chiang Mai has become a popular city for the Chinese diaspora families from the middle or upper middle class. These families have an intention to send their adolescent children overseas due to the following reasons: (a) better international education resources; (b) a more conducive natural and social environment; and (c) a transition or springboard for further education in the Western developed countries. These "peidu mamas" are willing to travel painstakingly to unfamiliar foreign lands. They are prepared to withstand the transnational separation with their households even though they are young, well-educated and wealthy (Huang \& Yeoh, 2011). By uprooting and resettling themselves and their children, they have chosen to leave their husbands behind in China so that their husbands can continue working and providing them with the necessary financial support.

The Chiang Mai Huaren Jidu Church is patriarchal in nature as it upholds certain notions of Confucianism pertaining to gender hierarchy in especial. By internalizing male domination and female submission, Chinese "peidu mamas" have to accept their inferior status while adjusting themselves to fit within the Chinese Christian social environment. Through participation observation, this study has discovered that many "peidu mamas" have chosen to introduce themselves as mothers of their children instead of mentioning their own names. Besides, the topics of their conversations usually revolve around their husbands and children. They often describe how their happiness has been derived from the members of their immediate families rather than themselves. In terms of church governance, the men usually dominate the roles of eldership and leadership with the emphasis on hierarchy, rationality, control, and exclusivism. These men make important decisions in the following fields: (a) planning church missions work; (b) developing church strategies; (c) resolving financial issues; (d) hiring associate pastors; (e) cooperating with other churches; (f) supervising prayer meetings; and ( $g$ ) organizing church activities. In contrast, the women adopt a more pious but submissive role characterized by religiosity and vulnerability while performing caretaking and homemaking duties in church. Creating a homelike ambience for church members, these women carry out duties such as preparing food, cleaning premises, leading worship choir, taking care of children, and worshipping in church.

Today, China continues to witness a religious enchantment in the context of modernity, especially towards Christianity. Yang (2014) estimated that Christians in China could exceed 160 million by 2025 . China will have the largest number of Christians in the world in 2030 within the dynamic social, political, and cultural milieus. With the impact of modernization, a question has been raised: "Why do the middle-class, well-educated, and non-religious Chinese women who have been brought up in a secular Chinese society characterized by relative equality choose not to be converted to Christianity in China, but have voluntarily chosen to do so in a 
patriarchal Christian community, which has apparently been designed to perpetuate their subordination in Chiang Mai?"

\section{LITERATURE REVIEW}

Many scholars have paid attention to the gender paradox of women's participation in patriarchal religious communities (Brusco, 1995; Cucchiari, 1990; Fällman, 2008; Martin, 2003). Scholars have successfully challenged the conventional interpretations of feminine engagement with regards to religious patriarchy by taking the account of women's religious activity (Brusco, 1995; Chong, 2006; Griffith, 1997; Ozorak, 1996; Stacey, 1990). Exploring the gender paradox between the female experiences of traditional religious teachings, Ozorak (1996) discovered that the church community, featuring mainly women, is supportive of women encountering personal difficulties, and has assisted them to work together and form close relationships with their surrounding communities. Examining the meaning of religious submission in the Korean context, Chong (2006) focused on the motivations behind women's consent to patriarchy that are rooted in women's contradictory desires regarding the family system and their evoked ambivalent subjectivities. Glock (1967) proposed that a single mother or a widow may be more likely to be converted to a new religion for family benefits (Glock, 1967). Alumkal (2003) regarded the Bible as the primary source of gender hierarchy in the Christian diaspora churches. Kandiyoti (1998) defined the "patriarchal bargain" as a set of concrete rules and constraints within which women must strategize to survive in a patriarchal society. Subsequently, this provides the opportunities for the women to reshape gender relationships through "patriarchal bargain" while opening a new area of struggle and renegotiation in gender relations (Kandiyoti, 1988). Other studies have also shown the relativity between religiousness and marital satisfaction where a high church attendance rate is significantly related to a lower divorce rate (Lambert \& Dollahite, 2008; Mahoney et al., 2001). These studies addressed several salient issues as follows: (a) the nature and dynamics of contemporary gender relations; (b) the negotiation by religious women with their challenges precipitated by modernity and social change; (c) gender negotiation; and (d) unpredictable consequences for altering gender dynamics. Through these studies, the views of patriarchy Christianity as monolithic sources of oppression in women have been debunked, and the perspective that women are victims of male domination has been challenged.

\section{METHODOLOGY}

This article is based on issues related to the Chinese gender roles and family norms. It focuses on the problems of patriarchal power and how the "peidu mamas" negotiate with the dominant ideology of patriarchy through the ethnographic investigation of their involvement in Chiang Mai Huaren Jidu Church. This article has also applied qualitative methods including formal and informal interviews, fieldwork, and participant observation. One of the researchers had served as a volunteer worker for several months at the Chiang Mai Huaren Jidu Church. Semi- 
structured interviews with 15 converted "peidu mamas" have been conducted. They have since become the members at Chiang Mai Huaren Jidu Church. In addition, ethnographic research has also been conducted with some church leaders. This study seeks to provide a sociological analysis of how Christianity has affected the Chinese women's self-identity and self-development by examining how these "peidu mamas" have interpreted Christianity to negotiate with the values in traditional Confucianism regarding gender and family values.

\section{Context: Gender Contradictions of the Modern Chinese Patriarchal Family}

This research has found that the involvement of the "peidu mamas" with the religious activities in Chiang Mai Huaren Jidu church is closely related to family and gender relations. It has provided a sociological understanding of their motivations behind their commitment in the patriarchal Christian church. This section uncovers the social and religious context of their religious conversion.

\section{Traditional Chinese Confucian Family and Gender Relations}

The traditional Chinese family system is built on principles found in Confucianism, which emphasizes on a strict hierarchical order of human relationships based on gender, age, and inherited social status. The principle of gender difference has served as the basis for strict gender segregation and role division where women occupy the "inner" sphere in subordination to the men at the "outer" sphere. Under the social system of traditional Confucianism, China had adopted a strict patrilineal, patrilocal lineage, which was maintained and affirmed through the rites of ancestor worship and filial piety while perpetuating a family line through the birth of male heirs. In the traditional Chinese ideology, men are honored and women are abased by the society (男尊女卑, nan zun nv bei). It is similar to "Yin/Yang" theory, which expresses how "yang" or male is superior and "yin" or female as inferior. The "Yin/Yang" theory also applies to family matter with perspectives such as "the wife should submit to her husband," "the husband must lead his family," and "the wife needs to take care of the children and attend to household chores while given deference to her husband" (相夫教子, xiang fu jiao zi). Due to the influence of Confucian values, the Chinese gender relations can sometimes be ritualized. These gender relations have been clearly defined as female subordination for Chinese women are to be deferential, silent and fertile, while the Chinese men are to be respected by outsiders through their wives acting as their faces (面子, mian $z i$ ).

\section{Socialist and the Late-Socialist Gender Ideology}

Apart from the Confucian values, the gender ideology of the socialist and late-socialist has persistently affected China. However, significant transformations have occurred in the structure and ideology of Chinese family and gender relations since 1949. According to Yang (1999), women were given equal rights in the spheres of politics, labor, and education through top-down legislation during the Maoist socialist era (1949-1976). Chinese women were encouraged by the Chinese state government to perform work previously reserved for men; however, women 
continued to play traditional mother roles at home (Yang, 1999). During the marketization era (1978-present), feminism is emphasized as the women's characteristic and the thinking that "women belong at home" has resumed. In this period, the Chinese state government has encouraged women to compete in the marketplace to enhance the "quality" (素质, su zhi) of their lives. This helps Chinese women to gain self-respect (自尊, $z i z u n$ ), self-confidence (自信, zi xin), self-reliance (自立, zi li), and self- strength (自强, zi qiang).

Furthermore, the Chinese government actively promotes gender equality in higher education and employment. Since then, the traditional family values and gender roles based on Confucianism regarding the social status of women have begun to transform. Females have gradually become informed citizens of modern society and their social status has been upgraded tremendously. In the family, the Chinese traditional kinship system has changed including (a) the weakening of the father's authority; (b) the reduction of man's superiority; and (c) the growing of respect for woman. In other words, due to the changes in the family structure, value system, and the education and employment opportunities for women, the status of the Chinese women in the sphere of family and gender has significantly improved.

\section{Crisis: Contradictions in the Family and Gender Relations}

With the "open economic" policy, China has undergone dramatic social changes. It has been transformed from a poor, agricultural society into a quasimodern country with the single-minded pursuit of economic development and modernization. These dramatic changes generated by education and the forces of modernity have brought about enormous social and cultural contradictions. These contradictions can be discussed by a concentrated expression regarding the issues of family and gender relations.

Chinese modernity has significantly improved the material life of the people. In this process, women can experience the following aspects: (a) emancipation from heavy household duties; (b) enablement to look into their personal needs; and (c) redefinition of their domestic roles and identity. At the same time, the western values have exerted considerable influence on the culture of the Chinese family, particularly regarding the ideals of romantic love and companionate marriage. The powerful clash between Chinese modernity and the ideology behind the traditional Confucian family has inadvertently perpetuated changes and has refashioned the lifestyle of women within the modern patriarchal Chinese family. These changes have given Chinese women the space to expect new ideas concerning their roles, which they have never experienced before. In short, China modernity has allowed the women to bring about modern ideas towards marriage and family life based on a bond of mutual love, respect, gender equality with less patriarchal oppression.

Seemingly, Chinese women are literate and well-educated while enjoying the same modern life benefits as men. In fact, they are able to make more decisions by themselves. Nonetheless, in the modern Chinese society, major conflicting ideas still persist between modern developments and the values of traditional Chinese patriarchy, especially in gender status and relations. In reality, Confucianism's ethical codes and practices are still prevalent in creating a gender-based division and 
stereotyped social roles between women and men. As a requirement for Chinese women, marriage has been ideologically reinforced amongst women while confining them to a restricted idiomatic space of "wise mother and good wife." Today, the notion of "wise mother and good wife" has added childcare and educational managerial role for her children to a woman's long list of duties. In other words, it has become the responsibilities of women to direct their children in the path of receiving prestigious education and attaining a successful life. As a result, some middle-class women quit their jobs and careers in order to be fully responsible for their children's education. Also, these women do not hesitate to go all out, including spending all their money, for the sake of their children's education. In fact, the nurturing and upbringing of their children has rest squarely on the shoulders of these women who have sacrificially provided unpaid labour.

The "peidu mamas" in Chiang Mai, as well as many mothers in China, bear the responsibility for ensuring their children's academic success. They are willing to take their children to study abroad while letting their husbands remain in China to work for securing financial provision. The Chinese mothers' enthusiasm for their children's education has implied the intensifying contemporary role of Chinese women in managing their children's education reflecting China's neoliberal transformation. "Peidu mamas" usually exert their economic power and put tremendous pressure on their children by meddling with their children's involvement in school activities and visiting the teachers to ensure their children's academic performance. They invest their energy and time heavily on their children beyond their self-care; thus, it indicates the dominance of patriarchal system that promotes the ideology of self-loss in Chinese women instead of reclaiming selfagency or self-development. In this sense, these "peidu mamas" are symbolically regarded as the extension of their husbands' social position of wealth and influence outside the domestic domain.

Although "peidu mamas" are well-educated, their domestic dilemmas are apparent. As seen, while the restrictions of the current patriarchal family system in the modernization process have declined, there is a resurgence of Confucian values in the modern Chinese society. The burdens of child-rearing and education have caused the women to withdraw themselves from the path of independence and domesticity. They could neither make the best of their educational capital and talents nor implement their personal life goals. On the contrary, supervising their children's numerous study activities and looking after their children's basic physical and emotional needs have already caused much mental stress to the "peidu mamas." Although they do not have much economic woes, they live in a social dilemma trapped in an ambiguous sense of discontentment due to their domestic identities. The intensive and stressful child-rearing, used to be shared among the extended family members, has now been exclusively borne by the "peidu mamas" themselves.

Moreover, due to the transnational arrangement of physical separation, the couples face plenty of social and personal problems, such as class differences, extramarital issues and divorces. Today, the rising number of marriage infidelities has become a serious social problem affecting gender roles in Chinese society. Many men have secretly kept mistresses (包二奶 bao er nai, 小三 xiao san). This immoral 
behavior threatens many Chinese families, but the Chinese government is still unable to find a suitable way to solve this social problem. According to the statistics provided by the National Working Committee under the State Council seeking to protect children and women, the divorce rate in China has been increasing annually. There were 4.15 million couples who divorced in 20191. In this context, many "peidu mamas" have highlighted their concerns over the possibility of experiencing extramarital problems because they could not physically live with their husbands as couples.

The reason behind the participation of the "peidu mamas" in religious activities at Chiang Mai Huaren Jidu Church is a complex one. The Chinese socialist and late-socialist gender ideologies, as well as the influences of Confucianism have placed the "peidu mamas" in a paradoxical situation against their perceived "Western biblical modernity." According to the informants, while the reasons for religious conversion are varied, most of conversion trajectories have revolved around their domestic crises. Based on their narratives focusing on their marriage relationships and insurmountable domestic issues, the "peidu mamas" have revealed the underlying contradictions in family and gender relations. As such, these contradictions help us comprehend how the religious participation of "peidu mamas" in the patriarchal Christian church in Chiang Mai has become a central means for them to deal with their domestic dilemmas arising from the current crises or contradictions of gender and family in the modern Chinese patriarchal families.

\section{Gender Paradox in Chinese Confucianism Patriarchal Christian Church}

Based on the preceding discussion, the young and well-educated "peidu mamas" are subordinated within the patriarchal Christian church. They are kept from positions of authority in making important decisions while being relegated to church helpers proving supportive services. This study has unraveled the submissive status of the "peidu mamas" as vigorously and ideologically sustained both by traditional Chinese Confucianism and the Christian requirements of women.

The ideologies of the patriarchal interpretation in Christianity and Confucianism have instilled in the "peidu mamas" certain gender directives and ways. In this study, the Chinese Christian church has asserted a divinely sanctioned set of Christian beliefs, which has continued to be deeply rooted in Confucianism portraying women as inferior to men. It reflects the essential values of Confucianism in family and gender relations upholding the prerequisites for family harmony and cohesion through the following: (a) male's absolute and inherent superiority; (b) the female's total obedience; and (c) female's endurance.

Several pastors have attributed the current state of family crises to women's deviation from the Chinese traditional gender roles and social order, which led to a decline in marriage values. They have claimed that most family conflicts arise from women who either have been too strong and smart for their husbands or have been exerting too much power and leadership over their husbands. In this study, the

\footnotetext{
${ }^{1}$ http://www.nwccw.gov.cn/2020-01/20/content_278725.htm
} 
pastors have advised church women to abide by the Christian faith while trying to be a "good wife and smart mother." They need to fulfill the basic Christian gender order by placing themselves in the right position as a wife through performing the traditional duty in raising up their children and being submissive to their husbands.

The church pastors have been emphasizing how females should be silent and obedient. They have also encouraged church women to be conformed to the ideal image of the Confucianism as virtuous and submissive wives. To the church pastors, the women's unquestionable submission is a necessity to encourage their husbands' reciprocal love for them. The pastor's wife usually has to sacrifice her own identity in order to give her husband more support and assistance. As a result, together with the involvement of the pastor's wife, "peidu mamas" actively engage themselves in church activities, such as fundraising, choir singing, social works, food preparation, and teaching and looking after children. As the women delve deeper in their engagement with Christianity, they have become willing agents in preserving the image of Chinese traditional women in church.

The church conducts seminars and provides pastoral teachings to reshape woman's gender subjection both in the church and family by advocating that a woman should perform household work and should be submissive and meek towards the men. On 15 September, 2017, the pastor conducted a course on family relationships. During the session, the pastor stated that contemporary women have stepped away from the traditional gender roles and authority boundaries by violating the basic gender hierarchical principle and order prescribed in Chinese Confucianism. Further, the pastor explained how women pursuing their personal desires while acting according to their own ways in an assertive manner will cause family crises to occur and will inevitably suffer the consequences.

In her reflections, Lin (2017) spoke about the devastating consequences of the sins of arrogance and impatience provoking conflicts in her family. She stated: "With a higher education and an ability to earn a lot of money, I thought that I do not need to obey my husband. Yet, such thinking created lots of problems between my husband and I" (Lin, personal communication, September 13, 2017). Another "peidu mama" reflected: "Before I was converted to be a Christian, I had been the 'biggest one' in my family. My husband had to listen to me in everything, and because I was very demanding, we had lots of conflicts. Now, I realize that I am very insignificant, I need to depend on God while following God's words" (Wang, personal communication, June 8, 2018). Wang continued: "After the class, I realized that I was too self-centered. I always pressurized my husband and children to perform according to my expectations. I was too ambitious, and I focused too much on what my children could achieve. Now I realize that my controlling character and behaviour would have stirred up family conflicts and would have hurt my family" (Wang, personal communication, June 8, 2018). Thus, through the teaching sessions offered by the church, the women in the church have begun to adhere to women's ideal virtues, such as modesty and humility, so as to solve the conflicts they have had with their husbands. 
When the question of why the church does not have any female pastor was posed, Pastor Wang (2018) replied as follows: "The Bible has specifically addressed that the pastor must be a male, and the Bible has also addressed that the wife of a pastor has to be submissive to her husband (Eph. 5:22) and be supportive towards her husband (Gen. 2:18)" (Pastor Wang, personal communication, June 8, 2018). Many members in the church have also used the Bible to respond to this question by explaining that it is an issue of work distribution rather than having any notion that women are being inferior to men (Ms. Gao, personal communication, June 8, 2018).

Next, another question was posed as follows: "Does the patriarchal gender culture in the church means that the women are inferior to the men within a Christian church setting?" To that, Pastor Wang answered: "In Genesis 1:27-28, it is written that both men and women were created in the image of God, but men and women have different characters, women's desire will be for her husband, and husband will rule over his wife (Gen 3:16). God calls on women to submit to their husbands, not as inferior beings, but in all humility to allow their husbands to lead. This means that, in the eyes of God, women are equal to men..." (Pastor Wang, personal communication, June 8, 2018). Quoting from the book of Genesis, another pastor said assertively: "God created the man and then the woman. This order of creation means that the husband is the head of the family. At the same time, God used the rib of the man, instead of the man's foot, to create the woman. Hence, this means that the husband needs to love the wife" (Li, personal communication, 2018). In answering to the same question, Ms. Luo, a "peidu mama," cited Bible verses in her response as follows: "Women should assist men, and they should be ready to support and encourage them (Gen. 2:18). Females are usually more impulsive in making a decision, so we cannot assume important decision-making roles" (Luo, personal communication, September 20, 2017). However, some "peidu mamas" use church relationships in discussing this issue. For instance, Ms. Gao highlighted: "In our churches, we address each other as sisters or brothers. Hence, we are equal, and we are all children and servants of God" (Ms. Gao, personal communication, June 13, 2018).

In summary, this section has described how the Chiang Mia Huaren Jidu Church utilises the cultural norms from both the Bible and the Chinese Confucianism to interpret women's subordination and their status in the Chinese Christian diaspora church. The middle-class Chinese women in this study are young, well-educated "peidu mamas" who are enthusiastic in attaching themselves to the church. Instead of feeling inferior to their male counterparts, "peidu mamas" are in the opinion that they are respected and receive lots of love from the church. In other words, the female members, consisting of "peidu mamas," have preferred psychological comfort over positions of leadership and power.

\section{Chinese Christian Church: Women's Space, Women's Community}

The first stage of Christian encounter for the "peidu mamas" in Chiang Mai consists of preparatory socialization providing them with a Christian-based community. In this community, the Christians whom the "peidu mamas" encountered have given them the exposure to the Christian faith, values, and good 
conduct. This introductory stage has become a motivation for the "peidu mamas" to journey into Christian conversion.

There are more than 40 "peidu mamas" in the "WeChat" group of Chiang Mai Huaren Jidu Church. Constituting the majority, these believers can be considered as the most enthusiastic group of church members for they fill crucial roles as dedicated church helpers and passionate evangelists. For some "peidu mamas," church participation entails a kind of deep Christian commitment in performing "God's works." Besides, based on the interviews, several narratives suggested that their religious involvement is positively related to the support they get from the church where their roles in the family and community connote a far broader meaning beyond mere spiritual and religious ones (Gao, Xin, Jing \& Fan personal communications, June 13, 2018). For them, the church offers them meaning at both institutional and spiritual dimensions.

The Chinese Christian community in Chiang Mai city has assumed an essential function in facilitating religious conversion for the women. As many Chinese women have minimal contact with local people due to the language barrier, the church has given them an alternative, holistic community. Prioritizing their interests, the "Chinese 'peidu mamas'-centered community" provides spiritual, emotional and psychological spaces of support. Notwithstanding the church being patriarchal, the family-like social community focusing on females' social activities has provided the "peidu mamas" a regular face-to-face opportunity for social interaction and connection; thus, it has been a huge attraction for "peidu mamas." To them, the church is more than a place for worship or mere performance of Christian duties. In contrast, it has become a social interaction platform or a home away from home. By attending the church gatherings, the "peidu mamas" have learnt to cope with their emotions, and they have acquired skills in solving the conflicts and constraints in their families. As can be seen, the "peidu mamas" are delighted to carry out their church duties, such as cooking, cleaning, visiting the church members who are sick, and sharing information with one another. As a result, they have improved their overall well-being as they have gained their extra-domestic space.

Migration has put an immense stress on the "peidu mamas" as their modern housewife tasks and subjective understanding have been undergoing massive reconfiguration. Consequently, they have felt lonely, isolated, and helpless. In response, the pastors expressed that the church recognizes the needs of this group of people who have brought their children to study in Chiang Mai by themselves. Being aware of their deprivation of families and friends, the church has attempted to fill the missing gap by providing them with an alternate family or a female community. Subsequently, the church focuses on members' social lives by providing a platform for the "peidu mamas" to build personal relationships within the church. Thereafter, the social activities of the church have spontaneously attracted and impressed many first-time churchgoers. The pastors usually invite the new attendees to have lunch together after the worship services. During these informal occasions, the pastors will talk with the newcomers like family members while rendering relevant assistance to them and introducing them to other members who could help them directly. These attractive social resources have incentivized first-time 
churchgoers in continuing to attend the church and being committed to church involvements. Through the church social gatherings and various activities, the "peidu mamas" develop frequent social interactions cultivating long-lasting and close friendships. Besides, through sharing life stories, solving problems together, establishing family-like bonding, and exchanging practical and personal experiences, they have helped to improve one another's well-being and family relationships.

The Bible class conducted by the church pastors has proven to be another essential channel for the "peidu mamas" to build relationships among women through mutual faith. The Bible study groups have practically functioned as "families within the bigger church family." By incorporating the social lives of the members and providing them with personal relationships within the church, these Bible study groups have served as the center for the "peidu mamas" to develop strong Christian faith and cultivate satisfying friendships via frequent social exchange and regular sharing of their lives and work experiences. As Ms. Huang said: "I really find it wonderful to experience frustrations, pains, grieved as well as happiness together. For me, the biblical doctrines are very difficult to understand, but the sharing of members during the discussion sessions has helped me to understand the doctrines more easily. Learning with them, my faith towards God and my commitment towards the church has increased" (Huang, personal communication, January 5, 2019). Ms. Huang's words have solidified the idea that the church is a hub with abundantly available activities where relationships are fostered.

This study has also discovered that the relationships between the "peidu mamas" and the church are closely associated with child-rearing. Before the Sunday worship service, "peidu mamas" always share the information about their children's studies or life experiences. Then, there is a short prayer ritual for the children where the children stand in a row before the members at the beginning of the worship service. At times, the children sing hymns too. Often, the children are taught by the pastors to be courteous towards non-Christian children. The prayer session for the children usually lasts about ten minutes, and then the pastor's wife directs the children upstairs, where she leads them in Bible studies or activities. Based on the interviews, "peidu mamas" have testified how their naughty children have transformed to become calmer and better in concentrating at studies after joining the church. The church also conducts Chinese classes for the children as requested by the parents. In this way, "peidu mamas" have received some relief from looking after and educating the children all by themselves. Through these activities, the church empowers the "peidu mamas" to develop their religious identity in huge faith-based family where the pastor and his wife are always ready to help them. The "peidu mamas" have also treated the church as their own home. They clean up the church, prepare Chinese food for all members, and celebrate Chinese festivals together. Through sharing child-rearing burdens, "peidu mamas" have made more friends in the church, and they are willing to invite their friends to join the church activities.

Church members also use new technology and social media to set up digital church communities. The "WeChat group" has become a very convenient platform 
for contacting members, publishing information, notifying meetings, discussing Bible matters, and facilitating online worship and prayer. Through the "Wechat group," the digitization of religious texts, such as the digital Bibles or other digital religious publications, has been widely used among Chinese diaspora Christians. Apart from the "E-Church" function, "WeChat group" allows the church to become an E-Community or a peers-networking platform. "Peidu mamas" have utilized the "E-Church Space" to set up a faith-based circle of friends to do favours for one another in areas of fitness, beauty and health.

The church's social family group and faith-based circle of friends are meant to attract the attention of the Chinese women at the initial stage. These groups act as a "family within Christianity," providing the "peidu mamas" with a social site. Effectively, through creating an extra-domestic space for the "peidu mamas," this social site motivates them to continue attending church gatherings while helping them to navigate the conflicts arising from migration.

Furthermore, the church community provides the "peidu mamas" with diverse opportunities to dedicate their lives and to fulfil their destinations. The "peidu mamas" usually take up the ministry of service in the church, such as cooking, cleaning, and taking care of children. These works of service indicate their submissive status; however, the "peidu mamas" show delight when participating in the ministry of service. This is because they have received due recognition from the pastors and other members. Thus, this has indicated that their church involvements are related to a subtle form of social interaction circle or social recognition reward. They relate and express their self-fulfillment and satisfaction with church involvement while viewing their service in the church as the evidence of their religious piety. Some of them stated: "We do acts of service in the church because we have faith in God. The Bible tells us to believe in Him and to be involved in church ministry" (Grace, Gao, Yang, Xin, personal communication, September 14, 2017). Despite the existence of the distinct submissive status of women in the church, the formal and informal "rewards" from the church members have encouraged the women to participate enthusiastically in the ministry of service of the church.

In summary, this section has demonstrated that the "peidu mamas" in Chiang Mai Huaren Jidu Church serve in Chinese women community of the church to attract the young peidu mamas. Through church ministry of service, they regain their worth in the "household of faith" and are rewarded with recognition and approval from the church members. The next section is the analysis of how the "peidu mamas" utilize the "patriarchal bargain" to negotiate with the traditional gender role and family relationship.

\section{Dynamic gender paradox through patriarchal bargain}

This article has tested Kandiyoti's theory by establishing that "peidu mamas" have attempted to renegotiate their material relationships powerfully in the Christian and traditional Confucian patriarchal contexts by employing submission. They use submission as a tool to bargain for family harmony, and through subtle suggestions, they have influenced their family members' behavior for the better. Through showing their sincere obedience and other submissive acts to their 
husbands, "peidu mamas" have inspired their husbands in correcting wrongdoings and improving conduct.

Due to the dramatic changes associated with their migration process where their husbands have to remain in China to work, "peidu mamas" face huge challenges in their marriages. From the interviews, it has been discovered that the greatest marital challenge lies in the lack of effective communication. To help the "peidu mamas" solve this problem, the church has arranged many courses on improving family relationships and equipping them with the specific methods and effective tactics in carrying out obedience appropriately and successfully. The pastors teach the "peidu mamas" to obey their husbands, which is an effective way to reshape the gender hierarchy. The church teaches the women to abide by the biblical doctrines and submit to their husbands to attain harmonious families while advising the husbands to love and respect their wives in return. Through the wives' submission, the husbands receive a significant amount of respect and a feeling of having "face" (面子, mian zi). When the authority of the husband in the family has been re-established, the paternal system is recovered. As men seem hard to give up their privileges, these husbands willingly love their wives more as they have found their male privileges intact in the Christian church.

Pastors assert that when a wife submits and obeys her husband sincerely, she is giving her husband a superior position and special authority to reshape their family order. To this, Pastor Zhao elaborated: "Without the wife's submission to her husband, God would not use the family. The wife needs to obey her husband unconditionally in the way she obeys Jesus Christ; conversely, the husband should be the leader both in the spiritual and the material spheres." (Pastor Zhao, personal communication, September 6, 2018).

The "peidu mamas" who had previously questioned the doctrines of female submission have now accepted the teachings of the church. They have begun to see that being an obedient wife is the way to solve their family conflicts. They highly endorse the gender ideology of the church because the act of submission has proven to be effective in negotiating love and respect, especially in the context of better marital relations. They have testified that their marriages have improved after they have accepted the submission "tactic." As one interviewee elaborated: "The family relationship course has taught me how to develop loyalty and respect in my family. Previously, I simply made decisions about everything, but now I have learnt to solicit my husband's opinions. This method has made our marriage life more harmonious" (Gao, personal communication, September 6, 2018). Another "peidu mama" narrated a similar experience: "Pastor Li addressed the family problems with the biblical teachings of gender role. As the husband is head of the family, the wife should therefore follow her husband under the 'one husband, one wife' covenant" (Huang, personal communication, September 5, 2018).

Besides, many informants have stated that their willingness to submit to their husbands has enabled their husbands to give them the solicitude they need. According to Jiaojiao, she put it as follows: "The relationship between my husband and I was quite tense, especially after I have first moved to Chiang Mai with my 
daughter. One day, I just followed the advice given by my pastor. I washed my husband's feet when he visited us. I tried to let my ego down to obey him. My husband was moved by my actions and behaviour, and since then, he has started to change a lot. He gives me more respect and warm love than ever. He has also followed me to the church and has since received water baptism too" (Jiaojiao, personal communication, August 4, 2018). Jiaojiao's testimony has illustrated how "peidu mamas" can gain more when they voluntarily obey men both in the church and in the family. Ironically, they get what they need from their marriage lives through the patriarchal bargain.

The pastor couple acts as the role model for the church members. The pastor always gives the respect due to his wife, and his wife always supports him in his pastoral duties. The couple is never quarrelsome regardless of whether they are performing pastoral duties in church or in daily life. An interviewee once gave a clear explanation about the leaders in the church: "The pastors set an excellent example for us to follow. I realize that when my husband and I have the same belief, we can set up a strong foundation for our family. The couples in the pastoral ministry are the best models for the church members to follow because they have good values and strong commitment in their marriage" (Fen, personal communication, September 6, 2018). Additionally, Ms. Yue said, "I recommend my friend to marry a Christian. Christian marriage can give you true happiness, and only [when] two persons have the same belief, you can get really harmonious. Hence, I will encourage my daughter to marry a Christian when she grows up" (Yue, personal communication, September 6, 2018).

The Chiang Mai Huaren Jidu Church organizes their activities based on the sacred writings of Christianity contained in the Bible, such as "one husband, one wife" and "abstain from sex before marriage" while encouraging "peidu mamas" to bring along their husbands and children to join the church services together. Throughout the process, their marriages have become more stable as they adhere to the biblical teachings. When both husbands and wives submit to the firm principles of Christian morality despite the women starting from marginalized positions both in the church and in the family, the couples typically gain more in their families and enjoy healthy marriage lives.

Additionally, many "peidu mamas" have commented that the church has helped them to improve their relationships with their children. For instance, some of them described it as follows: "Before that [course], when my children were very naughty, I would also be infuriated with them. However, I have learnt to pray. I have become a calm person, and my son has also understood me most of time" (Zhang, Yue, and Wang, personal communications, October 20, 2018).

In summary, the church teaches the "peidu mamas" to pray and invite their husbands to attend Church by emphasizing women's submission to their husbands and husbands' loving their wives. Through these teachings, their family relationships have improved drastically, and this has encouraged them to attend church activities devoutly. For "peidu mamas," Christianity has promoted their marital commitment and satisfaction. They have accepted the Christian gender 
submission doctrines through using "obedience" to resolve their domestic conflicts. Their church participation has also functioned as an essential means for them to reconcile their domestic situational constraints. Hence, the church has presented an acceptable option for them to deal with personal contradictions, especially in the area of negotiating family problems.

\section{Women and Christian Enchantment}

Although women apparently hold an inferior status in the church, they play an important role in religious enchantment. They are instrumental in bringing their children, husbands and parents to the church while actively inviting their friends and newcomers to join the worship or church activities. Based on the interviews, several "peidu mamas" in the church said that they wanted their children to marry a Christian when the children have become adults (Doris, Zhang and Xue, personal communications, December 20, 2017). The church women have devoted themselves to promoting Christianity. A church member once explicated this as follows: "After I was converted and became a Christian, I have gradually understood why the leaders of the church are zealous to preach the gospel. Now, I understand that it is the duty of a true Christian to let the non-Christians recognize the true God" (Yue, personal communication, September 5, 2017).

Christian "peidu mamas" in the Chiang Mai Huaren Jidu Church have demonstrated their zeal and abilities in all the church events. They do the work of evangelization, and they have successfully encouraged their friends and family members to be converted to Christianity as well. During the church services, they have also expressed their sincere faith while showing others the love of God.

\section{CONCLUSION}

Through the data analysis regarding the dynamics of Chinese women's participation in patriarchal Christianity and the paradoxical female gender submission at the Chiang Mai Huaren Jidu church, this article argues that Confucian patriarchal values are still prevalent. The pastors and the members of the church have made references to the Bible when explaining this prevalence. Through manifesting love and using familial terms ("sister" and "brother") in addressing one another, the church has provided a community for the "peidu mamas" that can balance hierarchy. This study has revealed that there is a balance in the gender hierarchy because they deploy "patriarchal bargain" in their negotiations. Although women are seemingly inferior in the patriarchal churches, the "peidu mamas" have enthusiastically involved themselves in the church's activities as a form of religious enchantment towards Christianity. In conclusion, patriarchal Christianity has provided women with a metaphorical "double-edged sword" as subjugation through patriarchal ideology on one side, and as a patriarchal bargaining tool for better gender roles and family values on the other. 


\section{REFERENCES}

Alumkal, AW. (2003). Asian american evangelical churches: race, ethnicity, and assimilation in the second generation. New York: LFB Scholarly.

Brusco, E.E. (1995). Formation of machismo: evangelical conversion and gender in colombia. Austin: University of Texas Press.

Chong, K.H. (2006). Negotiating patriating patriarchy South Korea evangelical women and the politics of gender. Gender \& Society, 20(6), 697-724. https:/ / doi.org/10.1177/0891243206291111

Cucchiari, S. (1990). Between shame and sanctification: patriarchy and its transformation in sicilian pentecostalism. American Ethnologist. 17(4), 687-707. https:/ / doi.org/10.1525/ae.1990.17.4.02a00050

Fällman, F. (2008). Salvation and modernity: intellectuals and faith in contemporary china. (rev. ed.) Lanham: University Press of America.

Griffith, R.M. (1997). God's daughters: Evangelical women and the power of submission. Berkeley: University of California.

Glock, C.Y., Ringer, B.B., and Babbie, E.R. (1967). To comfort and to challenge: a dilemma of the contemporary church. Berkeley: University of California Press.

Huang, S. and Yeoh, B.S.A. (2011). Navigating the terrains of transnational education: Children of Chinese 'study mothers' in Singapore. Geoforum, 42(3), 394-403.

Kandiyoti, D. (1988). Bargaining with Partriarchy. Gender and Society, [Special Issue to Honor Jessie Bernard], 2(3), 274-290.

Lambert, N.M., and Dollahite D.C., (2008). The threefold cord: marital commitment in religious couples. Journal of Family Issues, 29, 592-614.

Lehman, E C. Jr., (1985). Women clergy New Brunswick. N.J.: Transaction.

Mahoney, A., Pargament, K.I., Tarakeshwar, N., and Swank, A.B. (2001). Religion in the home in the 1980s and 190s: a meta-analytic review and conceptual analysis of links between religion, marriage, and parenting. Journal of Family Psychology, 15, 559-596.

Martin, B. (2003). The pentecostal gender paradox: a cautionary tale for the sociology of religion. In: R.K. Fenn (Ed.) The blackwell companion to sociology of religion. (pp. 52-66). Malden, USA, Oxford, UK, Melbourne, Australia and Berlin, Germany: Blackwell.

Ozorak, E.W. (1996). The Power, but not the glory: how women empower themselves through religion. Journal for the Scientific Study of Religion, 35(1), 1729.

Stacey, J. (1990). Brave new families: Stories of domestic upheaval in late 20 ${ }^{\text {th }}$ century America. New York: Basic Books.

Yang, F. (1999). Chinese Christians in America: Conversion, assimilation, and adhesive identities. University Park, PA: The Pennsylvania State University Press.

Yang, F. (2014). Christian estimate 'inflated' by Jiang Jie. Source: Global Times Published: 2014-4-25 